\title{
The Impact of Digital Marketing and Digital Transformation on Brand Promotion and Brand Positioning in Kosovo's Enterprises
}

\author{
Arta Istrefi-Jahja \\ South East European University, Kosovo \\ Jusuf Zeqiri \\ Faculty of Economics and Business, Tetovo South Eastern European University, \\ North Macedonia
}

\begin{abstract}
Digitalization is very important for every company in today's fierce competition. The development of Information Technologies has helped companies change means of reaching their clients and changing their working practices. The paper tries to assess digital marketing (DM) and digital transformation (DT) techniques that impact enterprises in Kosovo in the process of their brand promotion and brand positioning using google analytics, social media, e-commerce, search engines, mobile apps, or other digital channels. DT is profoundly important to every company, yet the correlation between DT, brand promotion, and brand positioning for Kosovo's enterprises has not been researched a lot. With the DT, many companies are redefining business procedures and marketing strategies. The research will collect data using a survey with 150 companies generated by the Kosovo Business Registration Agency. Partial Least Square is used to analyse the collected data. Structural Equation modelling is used to assess the relationship between exogenous and endogenous variables used in the research proposed model. A moderation effect is used to test whether COVID-19 or the company's size is linked to the usage of DM and DT. The results are expected to reveal that DM and the digitalization process of enterprises affect brand promotion and brand position. The findings also imply that social media are widely used relative to other marketing channels. Companies that use DM and invest more in technology have better chances to promote and position their brands.
\end{abstract}

Keywords: digital marketing, digital transformation, brand positioning, brand promotion, Kosovo

JEL classification: M30; M31

Paper type: Research article

Received: Apr 23, 2021

Accepted: Aug 12, 2021

DOI: $10.54820 / U P Q N 1850$ 


\section{Introduction}

In today's world, where access to information is easy, and the supply for various products is high, loyalty and trust are crucial reasons consumers will buy certain products (Mishra et al., 2016; Pratminingsih et al., 2013; Alhabeeb, 2007). The right marketing strategy is crucial for any company. As technology advances rapidly (Customer relation management, salesforce, google analytics, etc.), e-electronics, brand promotion and brand positioning play an important role in digital marketing and transformation (Melović et al., 2020). Brand positioning is defined as a process of creating own image, positive association, and values in consumers' minds to create a sustainable trademark image (Fayvishenko, 2018). Different target groups prefer a certain form of online or traditional advertising. For Millennials, digital marketing is highly effective, motivating them to visit a website and write online reviews (Smith, 2012).

There is a lack of research for the Kosovo market on this topic and transition countries. The current research was conducted by Sadiku (2019) on higher education and digital transformation, while Limani et al. (2018) researched banking systems and digital technology adoption of Electronic Data Interchange. Some research has been done on brand awareness, showing an increasing trend of enterprises creating a brand for their products (Ukaj, 2016). Other research measures the effects of e-marketing on brand loyalty, showing that e-marketing communication is a key factor in building a brand image, customer satisfaction, and loyalty towards brands of mobile operators in Kosovo (Mullatahiri et al., 2019). However, there is no research on the impact of digital transformation and digital marketing on branding and positioning, per se.

Digitalization is under-studied for the Kosovo market. Computers were initially used for financial records mainly, but the Kosovo market was moving fast on adopting new technology. An open data source shows that internet penetration in Kosovo was $91 \%$ in January 2021 , an increase of $9,7 \%$ since January 2020 . Kosovo has much higher internet penetration than North Macedonia (82\%) and Albania $(69,6 \%)$. In addition, $103 \%$ of the total population had a mobile connection, while the number of social media users in Kosovo in January 2021 was equivalent to $56,9 \%$ of the total population (Hootsuite et al., 2019). These facts show the importance of digitalization for any aspiring companies who wish to work on brand promotion and brand positioning by using digital marketing tools and digital transformation.

On the other hand, $15 \%$ of the Kosovo population makes an online payment. Traditional businesses need to rethink their strategies from five perspectives: costumers, competition, data, innovation, and value. In today's world, companies suffer from attention. Therefore, we intend to shed some light on the impact of digital marketing on brand promotion and brand position and digital transformation on brand promotion and brand position for the Kosovo market. Pandemic COVID-19 was used as a moderator effect to test the impact on digital transformation.

The next part presents the background literature on digital marketing, digital transformation, brand position, brand promotion, and the effect of Covidl9 for developing the hypotheses. The following parts present the methodology, the results of the data analysis, a discussion, and conclusions of the findings. The paper ends with theoretical and practical implications derived from the study, and finally, the limitations of the study. 


\section{Literature Review}

The importance of digital marketing is constantly growing. A study shows how industrial companies characterized by complex selling processes can harness Web analytics to validate how digital marketing activities benefit their businesses. The article suggests that the benefits gained from marketing are determined by how an organization exploits the metrics systems under specific circumstances (Järvinen, 2016). Digital marketing does have a positive impact on brand promotion and brand positioning. Investing in digital marketing transforms to brand promotion and brand positioning. Moreover, the size of the company influences digital marketing and digital transformation. In other words, the larger the company, the higher the impact of DM, DT on brand promotion and brand positioning.

The number of social media users in Kosovo is increasing, where over $90 \%$ of the population uses it regularly. Findings from Çizmeci et al. (2015) indicate that digital marketing communication, which creates proactive content (Facebook, Instagram \& Twitter), will become more important in the future. A consumer data collection was analyzed by Krishnaprabha et al. (2020), which demonstrates that digital marketing activities have a high influence in building brand awareness as well as digital marketing activities allow on perceived quality, brand awareness, and brand loyalty. For micro-businesses, the degree of partnership and information are linked to organization context, whereas the level of training, service delivery, customer fulfillment, and competition are interrelated to the environment (Eze et al., 2020). For large companies, the investment in social media is increasing. However, the return of investment is a concern, leaving a question mark on how many likes and shares are translated to sales.

Nonetheless, there is a strong impact of social media on large companies as a digital marketing tool (Bogea et al., 2018). Investment in social media is important for brand promotion. Research by Yu et al. (2019) shows that previous experience with a brand's social media site is key to increasing clients' favourable site evaluation. It also demonstrates that having previous experience purchasing through social media will increase the brand promotion more than those who didn't have such experience. Another perspective from users was studied by Jibril et al. (2019), which shows that online-based-brand community on social media positively impacts consumer-brand engagement and user-brand relationship.

Word of mouth (E-WOM) still has an impact on brand experience. Recent research shows that the motivation of value co-creation positively affects the brand experience. E-WOM moderates the relationship between customer equity and brand experience (Yu et al., 2020). Thus, we come with the following hypotheses:

- H1: Digital marketing has a positive impact on brand position

- H2: Digital marketing has a positive impact on brand promotion

New technology or digital transformation (DS) has become an important tool that most businesses must adopt accordingly (Morakanyane et al., 2017). The digital transformation is defined by Fitzgerald et al. (2013) as the use of new digital technologies, such as social media, mobile, analytics, or embedded devices to enable major business improvements like enhancing customer experience, streamlining operations, or creating new business models.

A study by IDG (2019) shows that $63 \%$ of organizations say delivering an excellent customer experience as measured by customer satisfaction scores defines success as a digital-first business. Another study conducted by KPMG (2018) indicates that $67 \%$ of CEOs said that acting with agility is "the new currency of business; if we're too slow, we will be bankrupt". Technology is moving fast, while businesses are not always able to follow. Recent research by Guenzi et al. (2020) found that $75 \%$ of 
managers said that tools (from CRM to digital signature) are an integral part of the modern sales process, but only $15 \%$ said these tools were effective. So, for digital transformation to succeed, sales managers need to be selective, focusing on issues that have the biggest impact on their selective goals. The importance of brand loyalty and brand positioning was studied for different brands in Pakistan, revealing that a good marketing strategy can increase the market shares, particularly for new entrants. Even big companies like Coca-Cola and Gucci created a brand image and brand positioning through the investment of digital marketing (Ahmed et al., 2015).

Various companies use different strategies of brand promotion and brand positioning. A study shows that the usage of sports celebrities is an effective competitive source in brand positioning, which gives a competitive advantage over other competitors (Malik et al., 2014). As consumer behavior plays an important role in digital marketing strategy, firms are co-creating content with their consumers. The evidence shows that marketers must focus on relationship-based interaction with their costumes to improve digital marketing engagement (Tiago et al., 2014). Therefore, we propose the following hypotheses:

- H3: Digital transformation has a positive impact on brand position

- H4: Digital transformation has a positive impact on brand promotion

The COVID-19 pandemic has caused many problems to various companies in their business activities. Even though companies' digitalization has started earlier as a need for companies to offer online services and connect with customers, COVID-19 has accelerated the pace of the process of digitalization of companies. Thus, digitalization supports companies in overcoming problems caused by COVID-19 (Almeida et al., 2020). Because of many country lockdowns, many organizations and people have been forced to modify their working practices (Pandey et al., 2020), leading to an inevitable must for the use of digital technologies. Thus, COVID-19 has accelerated the adoption of digitalization technologies (Pinzaru et al., 2020). Therefore, we suggest the following hypothesis:

- H5: COVIDI9 has a positive impact on digital transformation

Based on the above, we have a research proposal model as depicted in Figure 1.

Figure 1

The Research model

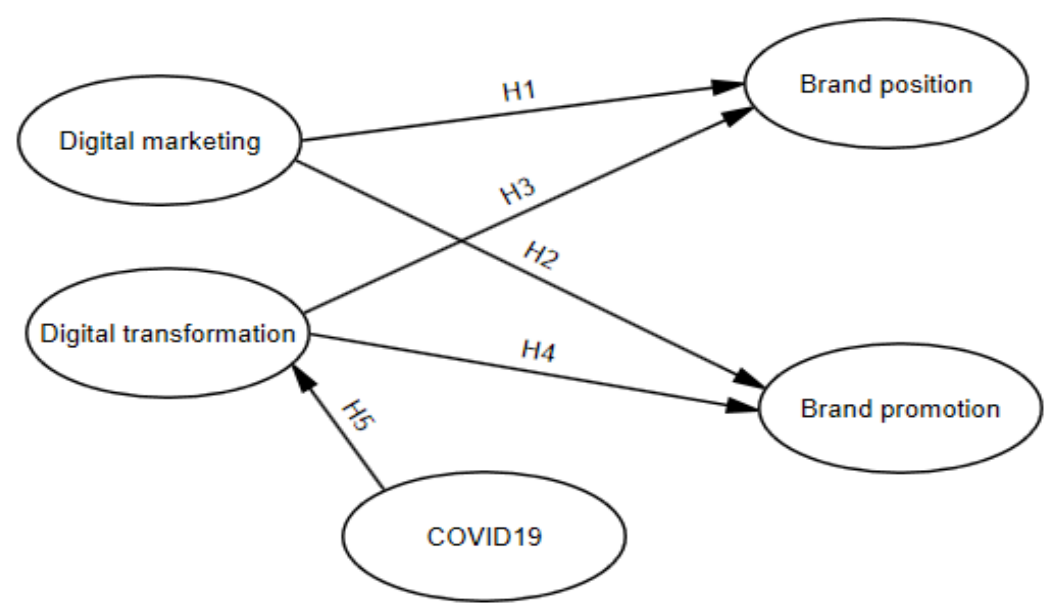

Source: Authors' work 


\section{Methodology}

The study's objective is to explore the impact that digital marketing and digital transformation have on brand promotion and brand position among companies in Kosovo. A structural questionnaire has targeted all sizes in Kosovo, micro, small, medium, and large companies. The questionnaire was sent to 150 companies and collected 120 questionnaires, and the response rate was $80 \%$. The data were collected through a web-based survey (using google forms) distributed online. The questionnaire was translated to Albanian, and respondents were asked to answer a five-point Likert scale ranging from strongly disagree to agree strongly. Table 1 presents the demographic profile of the respondents. Of the respondents, $47.5 \%$ belong to micro-sized companies, $32.5 \%$ to small-sized companies, $16.5 \%$ to mediumsized companies, and $3.5 \%$ to large-sized companies. Regarding the industry type of companies, $30 \%$ are in the production sector, $37 \%$ in services, and $33 \%$ in trade.

Table 1

Demographic profile

\begin{tabular}{lll}
\hline Company size / Industry type & Frequency & Percent \\
\hline Micro & 57 & 47.5 \\
Small & 39 & 32.5 \\
Medium & 20 & 16.5 \\
Large & 4 & 3.5 \\
\hline Production & 36 & 30 \\
Services & 44 & 37 \\
Trade & 40 & 33 \\
\hline Total & 120 & 100.0 \\
\hline
\end{tabular}

Source: Authors' work

The collected data were analysed using IBM SPSS and Partial Least Squares (PLS) with Smart PLS for assessing the measurement model and structural equation modelling (SEM). The respondents were assured their anonymity and confidentiality. The scales for measuring digital marketing, digital transformation, brand position, brand promotion, and COVID-19 were developed to review the existing literature (Table 2).

\section{Results}

To assess convergent validity, the outer loadings and the average variance extracted (AVE) must be reconsidered while assessing the convergent validity of the reflective constructs (Zeqiri et al., 2020). Hair et al. (2017) suggested a general rule for outer loading to be 0.708 . In cases when the outer loading of an item is between 0.4 and 0.7 , it needs to be removed if we want to achieve a good model fit. Therefore, the convergent validity evaluates the factor loadings, average variance extracted (AVE), Cronbach's alpha, and composite reliability. As shown in Table 3, the Cronbach's alpha values range from 0.651 to 0.843 , signifying that all values are above the recommended value of 0.60 accepted threshold for social sciences research (Ursachi et al., 2015). In addition, composite reliability values vary from 0.827 to 0.906 exceeding the proposed value of 0.70 . The average variance extracted (AVE) values range from 0.552 to 0.762 , which all are over the recommended value of 0.50 (Fornell et al., 1981). Therefore, convergent validity was achieved based on the results in Table 3. 


\section{Table2}

Research instrument description

\begin{tabular}{|c|c|c|}
\hline Construct & Code & Item \\
\hline \multirow[t]{7}{*}{$\begin{array}{l}\text { Digital Marketing } \\
\text { (DM) }\end{array}$} & DM1 & $\begin{array}{l}\text { We measure the influence of social media, which has an } \\
\text { impact on brand promotion }\end{array}$ \\
\hline & DM2 & $\begin{array}{l}\text { We measure the Google analytics, which has an impact on } \\
\text { brand promotion }\end{array}$ \\
\hline & DM3 & $\begin{array}{l}\text { Digital Marketing (social media, google analytics, } \\
\text { webpage, etc.) has an impact on brand positioning }\end{array}$ \\
\hline & DM4 & $\begin{array}{l}\text { The company uses social media as a form of band } \\
\text { promotion }\end{array}$ \\
\hline & DM5 & $\begin{array}{l}\text { The company uses a webpage as a form of band } \\
\text { promotion }\end{array}$ \\
\hline & DM6 & $\begin{array}{l}\text { The company uses SEO and google analytics to create a } \\
\text { digital marketing strategy }\end{array}$ \\
\hline & DM7 & $\begin{array}{l}\text { The company has implemented digital marketing in the last } \\
\text { five years }\end{array}$ \\
\hline \multirow{4}{*}{$\begin{array}{l}\text { Digital } \\
\text { Transformation } \\
\text { (DT) }\end{array}$} & DT 1 & $\begin{array}{l}\text { Production or services which we offer have automated } \\
\text { processes }\end{array}$ \\
\hline & DT2 & The company uses software systems for account purposes \\
\hline & DT3 & The company has dedicated employers in digital marketing \\
\hline & DT4 & $\begin{array}{l}\text { The company has invested in technology that helps on } \\
\text { digital transformation (tech defined as processes } \\
\text { automation, continuous investment in new machines, } \\
\text { e-commerce, CRM, salesforce et) in the last five years) }\end{array}$ \\
\hline \multirow[t]{4}{*}{$\begin{array}{l}\text { Brand Promotion } \\
\text { (BP) }\end{array}$} & Bprom 1 & $\begin{array}{l}\text { We do business promotion through sales agents, seasonal } \\
\text { promotion, or campaigns for brand promotion }\end{array}$ \\
\hline & Bprom2 & The company offers personalized products \\
\hline & Bprom3 & $\begin{array}{l}\text { We still use traditional marketing (sales agents, billboards, } \\
\text { flyers, etc.) }\end{array}$ \\
\hline & Brom4 & $\begin{array}{l}\text { Marketing through social media helps in distributing the } \\
\text { information for the company's brand }\end{array}$ \\
\hline \multirow[t]{5}{*}{$\begin{array}{l}\text { Brand } \\
\text { (BP) }\end{array}$} & BP1 & $\begin{array}{l}\text { Our company's approach is enough creative which is } \\
\text { related to brand positioning }\end{array}$ \\
\hline & BP2 & $\begin{array}{l}\text { Brand positioning of our company is different from our } \\
\text { competitors }\end{array}$ \\
\hline & BP3 & $\begin{array}{l}\text { We have a good communication form of brand positioning } \\
\text { which is clear and acceptable by our clients }\end{array}$ \\
\hline & BP4 & We have identified what makes our brand unique \\
\hline & BP5 & $\begin{array}{l}\text { Depending on our sales process, our company constantly } \\
\text { works on brand positioning }\end{array}$ \\
\hline \multirow[t]{4}{*}{ COVID19 } & COVI & $\begin{array}{l}\text { Pandemic COVID-19 had an impact on investing in the } \\
\text { automatization of processes }\end{array}$ \\
\hline & COV2 & We started online sales as a result of COVID -19 \\
\hline & cov3 & $\begin{array}{l}\text { The company invested in digital marketing as a result of } \\
\text { COVID-19 }\end{array}$ \\
\hline & COV4 & $\begin{array}{l}\text { From pandemic COVID-19, we plan the brand promotion } \\
\text { through the website and social media }\end{array}$ \\
\hline
\end{tabular}

Source: Authors' work 
Table 3

Construct reliability

\begin{tabular}{lllll}
\hline & Cronbach's Alpha & rho_A & Composite Reliability & AVE \\
\hline Brand position & 0.843 & 0.847 & 0.906 & 0.762 \\
Brand promotion & 0.651 & 0.717 & 0.847 & 0.736 \\
COVID19 & 0.840 & 0.954 & 0.895 & 0.743 \\
Digital transformation & 0.744 & 0.778 & 0.854 & 0.662 \\
\hline Digital marketing & 0.723 & 0.766 & 0.827 & 0.552 \\
\hline
\end{tabular}

Source: Authors' work

This study evaluates discriminant validity by using the heterotrait-monotrait ratio (HTMT). The HTMT values for all constructs must be below 0.85, as suggested by Hair et al. (2017). Table 4 shows the total HTMT value for all constructs below the recommended threshold of 0.85 ; therefore, all construct pairs have discriminant validity.

Table 4

Heterotrait-Monotrait Ratio (HTMT)

\begin{tabular}{lllll}
\hline & BP & Bprom & COVID19 & DT \\
\hline Brand position (BP) & & & & \\
Brand promotion (Bprom) & 0.558 & & & \\
COVID19 & 0.223 & 0.545 & & \\
Digital transformation (DT) & 0.571 & 0.78 & 0.453 & \\
Digital marketing (DM) & 0.718 & 0.64 & 0.498 & 0.753 \\
\hline
\end{tabular}

Source: Authors' work

Table 5 shows factor loadings, means, standard deviations, t-values, and VIF for all items in the construct. Outer loadings, as a rule, should be 0.708 or higher as recommended by Hair et al. (2017). Based on the values provided in Table 4, all item loadings range from 0.708 to 0.930 ; that is over the recommended threshold value. DM3 outer loading value is 0.542 , but it can be kept since the minimum AVE value of 0.5 has been reached (Ramayah et al., 2018). To check the collinearity issue, VIF values are used to check if the model is biased. According to Kock (2015), VIF values greater than 3.3 indicate a collinearity problem. Thus, denoting that the model is biased.

Table 5

Factor loadings

\begin{tabular}{llllll}
\hline & Loadings & Mean & STDEV & T-values & VIF \\
\hline BP1 & 0.851 & 3.88 & 0.99 & 17.715 & 2.038 \\
BP3 & 0.924 & 4.04 & 0.98 & 44.413 & 2.846 \\
BP5 & 0.842 & 4.22 & 1.01 & 18.626 & 1.920 \\
BProm1 & 0.912 & 3.29 & 1.36 & 37.87 & 1.304 \\
BProm3 & 0.799 & 2.85 & 1.45 & 11.567 & 1.304 \\
COV2 & 0.930 & 2.62 & 1.50 & 55.19 & 2.338 \\
COV3 & 0.926 & 2.81 & 1.36 & 34.82 & 2.659 \\
COV4 & 0.711 & 3.28 & 1.34 & 7.527 & 1.650 \\
DM2 & 0.838 & 3.32 & 1.43 & 23.906 & 1.861 \\
DM3 & 0.542 & 4.44 & 0.91 & 4.807 & 1.195 \\
DM6 & 0.838 & 3.06 & 1.35 & 19.215 & 1.908 \\
DM7 & 0.713 & 3.69 & 1.24 & 9.763 & 1.411 \\
DT2 & 0.708 & 3.98 & 1.29 & 9.556 & 1.307 \\
DT3 & 0.841 & 3.26 & 1.47 & 15.649 & 1.654 \\
DT4 & 0.882 & 3.45 & 1.47 & 31.208 & 1.751 \\
\hline
\end{tabular}

Source: Authors' work 
To test the hypotheses, we used bootstrapping technique. This technique helps assess the structural model, R-square $\left(R^{2}\right)$, beta, and t-values as recommended by Hair et al. (2017). The findings revealed support for all hypotheses (Table 6). Figure 1 presents the path model.

Table 6

Hypotheses testing results

\begin{tabular}{|c|c|c|c|c|c|}
\hline & Hypotheses & $\begin{array}{l}\text { Path } \\
\text { coefficient }\end{array}$ & STDEV & $\begin{array}{l}\text { T- } \\
\text { values }\end{array}$ & P-values \\
\hline H1 & Digital marketing -> Brand position & 0.433 & 0.105 & 4.133 & 0.000 \\
\hline H2 & Digital marketing -> Brand promotion & 0.203 & 0.097 & 2.086 & 0.038 \\
\hline H3 & Digital transformation -> Brand position & 0.198 & 0.094 & 2.101 & 0.036 \\
\hline H4 & $\begin{array}{l}\text { Digital transformation } \rightarrow \text { Brand } \\
\text { promotion }\end{array}$ & 0.453 & 0.076 & 5.954 & 0.000 \\
\hline H5 & COVID19 -> Digital transformation & 0.401 & 0.065 & 6.142 & 0.000 \\
\hline
\end{tabular}

Source: Authors' work

Figure 2 presents the path diagram. Digital marketing (DM) positively affected brand position (BP) (path coefficient $=0.433$, $\mathrm{t}$-value $=4.133, \mathrm{p}<0.000$ ). Thus, $\mathrm{HI}$, is supported. H2, Digital marketing (DT) has a positive significant effect on Brand promotion (Bprom) (path coefficient $=0.203$, $t$-value $=2.086, p<0.038$ ). In addition, $\mathrm{H} 3$ is also supported, i.e., digital transformation (DT) has a positive significant impact on brand position (path coefficient=0.198, t-value $=2.101, \mathrm{p}<0.036$ ). Furthermore, digital transformation (DT) has a significant positive effect on brand promotion (path coefficient $=0.453, t$-value $=5.954, \mathrm{p}<0.000$ ). Finally, $\mathrm{H} 5$ is also supported. Findings reveal that COVID19 has an impact on digital transformation ((path coefficient= $0.401, \mathrm{t}$-value $=6.142, \mathrm{p}<0.000)$.

Figure2

Path graph of the PLS-SEM model

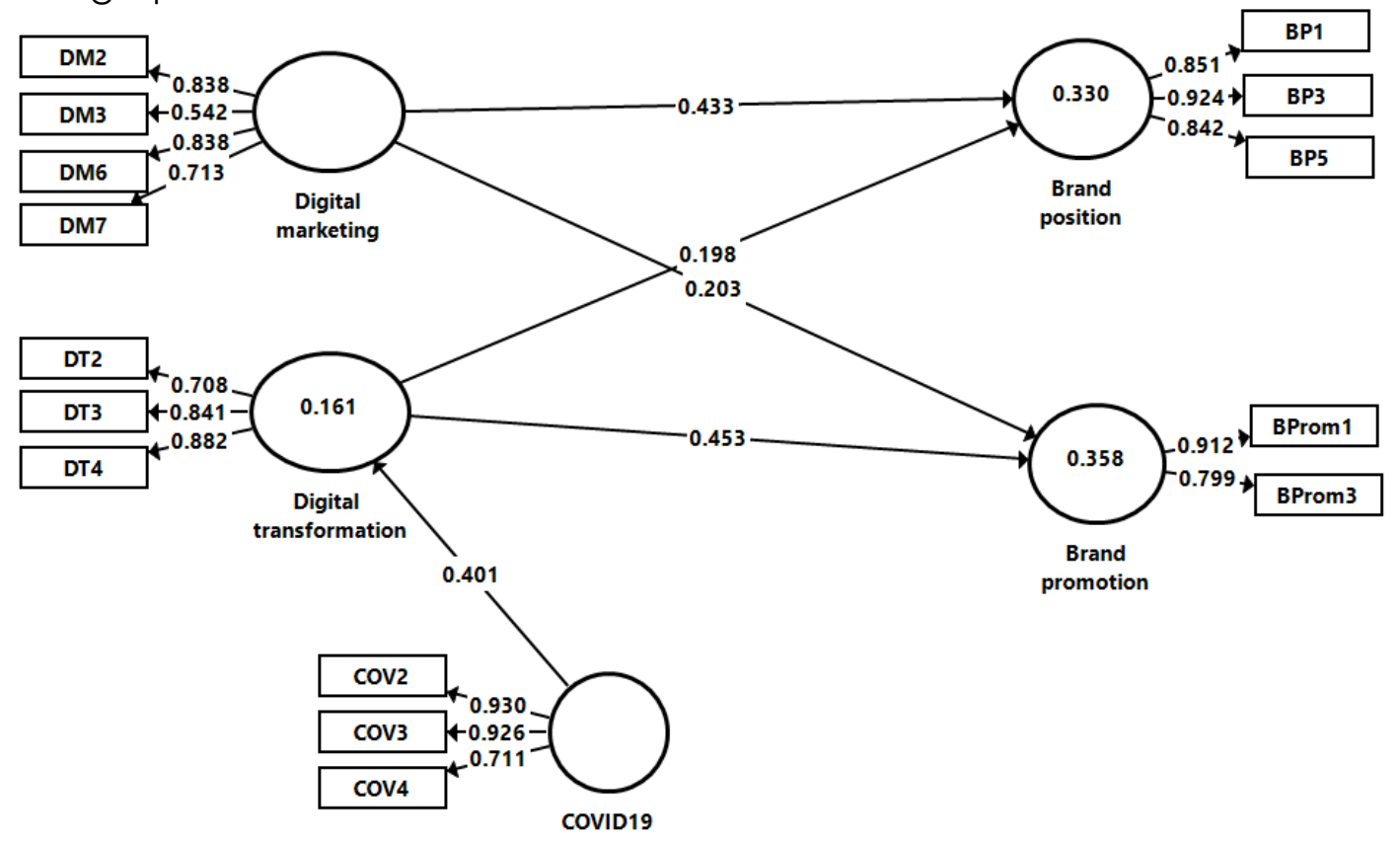

Note: DM1, DM4, DM5, DT1, COV1, BP2, BP4, Bprom2, Bprom4, and Bprom5 were removed from the model because of low loadings 
The model explained $33 \%$ of the variance in Brand position (BP) and $35.8 \%$ in Brand promotion (Bprom). The predictive relevance of the model was evaluated using Stone-Geisser's Q2 following a blindfolding procedure. The obtained values for $\mathrm{BP}\left(\mathrm{Q}^{2}=0.233\right)$ and Bprom $(\mathrm{Q} 2=0.240)$ denoting a good predictive relevance (Hair et al., 2017) (Table 7).

Table. 7 Determination of Co-efficient $\left(\mathrm{R}^{2}\right)$, Predictive Relevance $\left(\mathrm{Q}^{2}\right)$, and Effect size $\left(f^{2}\right)$

\begin{tabular}{|c|c|c|c|c|c|}
\hline Constructs & $\begin{array}{l}\text { Determination } \\
\text { of coefficient }\end{array}$ & $\begin{array}{l}\text { Predictive } \\
\text { Relevance }\end{array}$ & & Effect size (F2) & \\
\hline & R2 & Q2 & $\mathrm{BP}$ & Bprom & DT \\
\hline BP & 0.330 & 0.233 & & & \\
\hline Bprom & 0.358 & 0.240 & & & \\
\hline DM & & & $0.177^{*}$ & $0.041^{*}$ & \\
\hline DT & & & $0.037^{*}$ & $0.201^{* *}$ & \\
\hline COVID19 & & & & & $0.192^{*}$ \\
\hline
\end{tabular}

Note: $\mathbf{B P}=$ Brand promotion, $\mathbf{B p r o m}=$ Brand promotion, $\mathbf{D M}=$ Digital marketing, $\mathbf{D T}=$ Digital transformation; *Small effect 0 to $0.20,{ }^{* *}$ Medium effect 0.20 to $0.50, * * *$ Large effect more than 0.50

Source: Authors' work

Notwithstanding test model fit, model fit parameters need to be tested first. The Standard Root Mean Square Residual (SRMR) values are 0.094, denoting that the model is a considerably good fit for the saturated and estimated models. The SRMR values less than 0.10 or 0.08 are considered a good fit (Henseler et al., 2014). The second fit index used in PLS-SEM is NFI needs to be above 0.9 to denote an acceptable fit (Ramayah et al., 2018). In our study, the NFI value is 0.687 , below the proposed threshold.

\section{Conclusions}

The objective of this study was to explore the relationship of digital marketing and digital transformation on brand position and brand promotion among different-sized companies in Kosovo. Moreover, the study attempted to determine the impact that DM and DT have on BP and Bprom. In addition, this research tried to find out the effect that the pandemic of COVID-19 has on the digital transformation of companies in Kosovo.

Our findings show that digital marketing predicts brand position. This finding is similar and is supported by previous studies (Bogea et al., 2018; Melović et al., 2020; Niculescu et al., 2019). Therefore, the findings approve our prediction that digital marketing is an important tool for supporting companies in their effort to position themselves in the Kosovo market. Next, the findings showed that digital marketing (DT) predicts brand position among companies in Kosovo, which is similar to other findings like Melović et al., 2020; Fejling et al., 2019). The findings also revealed that digital transformation is a significant predictor of brand position among companies in Kosovo. The finding is supported by Morakanyane et al. (2017) and other previous publications (Ahmed et al., 2015; Reinartz et al., 2019). Therefore, our findings confirm our prediction that digital transformation impacts brand position. Moreover, the findings showed that digital transformation predicts brand promotion. The findings are in line with other publications, like, Melović et al. (2020). Finally, the findings showed that the pandemic of COVID-19 had a positive and significant impact on the digital transformation process of companies in Kosovo. The result is supported by other publications (Almeida et al., 2020; Pandey et al., 2020; Pinzaru et al., 2020). 
The significance of this research is to study the relationship between digital marketing and digital transformation on brand position and brand promotion motivation being the first study to focus on this issue in Kosovo. The study will also add to the literature a better understanding of the relationship between DM and DT and BP and Bprom on the other side. Moreover, this research provides some practical implications for companies and various other organizations to digitalize their business and marketing activities.

Last but not the least, the study has some limitations. The sample size is small, which cannot be generalized in other contexts. So, expanding the sample size could eventually lead to more reliable results from the research. Thus, further research can be expanded and using the company's size as a moderating variable to check whether the size of the company moderates these relationships, comparing more perspectives in their entrepreneurial motivation towards entrepreneurial. Finally, more extended research combining this model with other existing theories could provide more insights for future researchers.

\section{References}

1. Ahmed, R., Kumar, R., Baig, M., Khan, M. (2015), "Impact of Digital Media on Brand Loyalty and Brand Positioning", available at:

https://papers.ssrn.com/sol3/papers.cfm?abstract_id=2708527 (12 May 2021)

2. Alhabeeb, M. J. (2007), "On consumer trust and product loyalty", International Journal of Consumer Studies, Vol. 31 No. 6, pp. 609-612.

3. Almeida, F., Santos, J. D., Monteiro, J .A. (2020), "The Challenges and Opportunities in the Digitalization of Companies in a Post-COVID-19 World", IEEE Engineering Management Review, Vol. 48 No. 3, pp. 97-103.

4. Bogea, F., Brito, E. P. Z. (2018), "Determinants of social media adoption by large companies", Journal of technology management \& innovation, Vol. 13 No. 1, pp. 11-18.

5. Çizmeci, F., Ercan, T. (2015), "The Effect of Digital Marketing Communication Tools in the Creation Brand Awareness By Housing Companies", Megaron, Vol. 10 No. 2, pp.149-161.

6. Eze, S. C., Chinedu-Eze, V. C., Okike, C. K., Bello, A. O. (2020), "Critical factors influencing the adoption of digital marketing devices by service-oriented micro-businesses in Nigeria: A thematic analysis approach", Humanities and Social Sciences Communications, Vol. 7 No. 1, pp.1-14.

7. Fayvishenko, D. (2018), "Formation of brand positioning strategy", Baltic Journal of Economic Studies, Vol. 4 No. 2, pp. 245-248.

8. Fejling, T., Torosyan, E., Tsukanova, O., Kalinina, O. (2019), "Special aspects of digital technology-based brand promotion", in IOP Conference Series: Materials Science and Engineering, IOP Publishing.

9. Fitzgerald, M., Kruschwitz, N., Bonnet, D., Welch, M. (2013), "Embracing Digital Technology, "A New Strategic Imperative"'", Volume MIT Sloan Management Review.

10. Fornell, C., Larcker, D.F. (1981), "Structural equation models with unobservable variables and measurement error: Algebra and statistics", Journal of Marketing Research, Vol. 18 No. 3, pp. 382-388.

11. Guenzi, P., Habel, J. (2020), "Mastering the digital transformation of sales", California Management Review, Vol. 62 No. 4, pp. 57-85.

12. Hair, J. F., Hult, G. T. M., Ringle, C. M., Sarstedt, M., Thiele, K. O. (2017), "Mirror, mirror on the wall: a comparative evaluation of composite-based structural equation modeling methods", Journal of the Academy of Marketing Science, Vol. 45 No. 5, pp.616-632.

13. Henseler, J., Dijkstra, T. K., Sarstedt, M., Ringle, C. M., Diamantopoulos, A., Straub, D.W., Ketchen Jr, D. J., Hair, J. F., Hult, G. T. M., Calantone, R. J. (2014), "Common beliefs and reality about PLS: Comments on Rönkkö and Evermann (2013)", Organizational research methods, Vol. 17 No. 2, pp.182-209.

14. Hootsuite, We Are Social (2019), "Digital 2019 Global Digital Overview", available at: https://datareportal.com/reports/digital-2019-global-digital-overview (14 May 2021) 
15. IDG (2019), "Digital Business Study", available at: https://www.idg.com/tools-formarketers/2019-digital-business-research/ (14 May 2021)

16. Järvinen, J. (2016), "The use of digital analytics for measuring and optimizing digital marketing performance", available at: https://jyx.jyu.fi/handle/123456789/51512 (14 May 2021)

17. Jibril, A. B., Kwarteng, M. A., Chovancova, M., Pilik, M. (2019), "The impact of social media on consumer-brand loyalty: A mediating role of online based-brand community", Cogent Business \& Management, Vol. 6 No. 1, pp. 1-20.

18. Kock, N. (2015), "Common method bias in PLS-SEM: A full collinearity assessment approach", International Journal of e-Collaboration (ijec), Vol. 11 No. 4, pp.1-10.

19. KPMG (2018), "Global Manufacturing Outlook", available at: https://home.kpmg/xx/en/home/insights/2018/06/2018-global-manufacturingoutlook.html (15 May 2021)

20. Krishnaprabha, S., Tarunika, R. (2020), "An Analysis on building Brand Awareness through Digital Marketing Initiatives", International Journal of Research in Engineering, Science and Management, Vol. 3 No. 7, pp. 266-270.

21. Limani, Y., Stapleton, L., Groumpos, P. (2018), "The Challenges of Digital Transformation in Post- Conflict Transition Regions: Digital Technology Adoption in Kosovo", IFAC-Papers Online, Vol. 51 No. 30, pp. 186-191.

22. Malik, A., Sudhakar, B. D. (2014), "Brand positioning through celebrity Endorsement-A review contribution to brand literature", International Review of Management and Marketing, Vol 4 No. 4, pp. 259-275.

23. Melović, B., Jocović, M., Dabić, M., Vulić, T. B., Dudic, B. (2020), "The impact of digital transformation and digital marketing on the brand promotion, positioning and electronic business in Montenegro", Technology in Society, Vol. 63, p. 101425.

24. Mishra, M.K., Kesharwani, A., Das, D. (2016), "The relationship between risk aversion, brand trust, brand affect and loyalty", Journal of Indian Business Research, Vol. 8 No. 2, pp. 78 97.

25. Morakanyane, R., Grace, A. A., O'Reilly, P. (2017), "Conceptualizing Digital Transformation in Business Organizations: A Systematic Review of Literature", Bled eConference.

26. Mullatahiri, V., Ukaj, F. (2019), "The effects of E-marketing communications on brand loyalty: The case of mobile telephone operators in Kosovo", The Journal of Distribution Science, Vol. 17 No. 6, pp.15-23.

27. Niculescu, A., Dumitriu, D., Purdescu, C., Popescu, M. A. M. (2019), "Enhancing Brand Value of Modern Organizations through Digital Marketing Tools and Techniques: A Study on Top Ten Romanian Companies", TEM Journal, Vol. 8 No. 1, pp. 171-181.

28. Pandey, N., Pal, A. (2020), "Impact of digital surge during Covid-19 pandemic: A viewpoint on research and practice", International Journal of Information Management, Vol. 55, p. 102171.

29. Pinzaru, F., Zbuchea, A., Anghel, L. (2020), "The Impact of the COVID-19 Pandemic on Business. A preliminary overview", International Academic Conference, Bucharest, October 15-16, 2020, pp. 721-730.

30. Pratminingsih, S. A., Lipuringtyas, C., Rimenta, T. (2013), "Factors influencing customer loyalty toward online shopping", International Journal of Trade, Economics and Finance, Vol. 4 No. 3, pp. 104-110.

31. Ramayah, T., Cheah, J., Chuah, F., Ting, H., Memon, M. A. (2018), Partial least squares structural equation modeling (PLS-SEM) using smartPLS 3.0., Pearson, Kuala Lumpur, Malaysia.

32. Reinartz, W., Wiegand, N., Imschloss, M. (2019), "The impact of digital transformation on the retailing value chain", International Journal of Research in Marketing, Vol. 36 No. 3 , pp. 350-366.

33. Sadiku, A. (2019), "Digitalization of Banking Services in Kosovo: Trends and comparison with the neighbouring countries", Piran, Slovenia, pp. 379-392.

34. Smith, K. T. (2012), "Longitudinal study of digital marketing strategies targeting Millennials", Journal of Consumer Marketing, Vol. 29 No. 2, pp. 86-92.

35. Tiago, M. T. P. M. B., Veríssimo, J. M. C. (2014), "Digital marketing and social media: Why bother?", Business horizons, Vol. 57 No. 6, pp. 703-708. 
36. Ukaj, F. (2016), "The Role and Importance of Brand in the Marketing of Small and MediumSized Enterprises in Kosovo", International Journal of Marketing Studies, Vol. 8 No. 6, pp.5257.

37. Ursachi, G., Horodnic, I. A., Zait, A. (2015), "How reliable are measurement scales? External factors with indirect influence on reliability estimators", Procedia Economics and Finance, Vol. 20, pp. 679-686.

38. YU, X., Yuan, C. (2019), "How consumers' brand experience in social media can improve brand perception and customer equity", Asia Pacific Journal of Marketing and Logistics, Vol. 31 No. 5, pp. 1233-1251.

39. Yu, X., Yuan, C., Kim, J., Wang, S. (2020), "A new form of brand experience in online social networks: An empirical analysis", Journal of Business Research, Vol. 130, pp. 426-435.

40. Zeqiri, J., Kareva, V., Alija, S. (2020), "The Impact of Blended Learning on Students' Performance and Satisfaction in South East European University", in Proceedings of the ENTRENOVA-ENTerprise REsearch InNOVAtion Conference, Vol. 6 No. 1, pp. 233-244.

\section{About the authors}

Dr. Jusuf Zeqiri holds the position of Associate Professor of Marketing and International Business at the South East European University in Tetovo, Macedonia. Dr. Zeqiri also holds a Master of Science in International Trade from SS. Cyril and Methodius University in Skopje, a Ph.D. from the SS. Cyril and Methodius University Skopje. Dr. Zeqiri has also gained an online DBA from SMC University, Switzerland. Dr. Zeqiri has more than 20 years of teaching experience in various institutions. He taught for 18 years at the undergraduate and graduate levels at South East European University in Tetovo, Macedonia. He held lectures as a Visiting Professor at many domestic and international educational institutions in Southeast Europe. He has supervised many students in their master's and doctorate thesis. Dr. Zeqiri has published many research papers in peer-reviewed scientific journals and reviews many international journals. The author can be contacted at email j.zekiri@seeu.edu.mk

Arta Istrefi-Jahja is a Ph.D. student at the South East European University, Macedonia. She is Ecosystem Facilitator at the Swiss Entrepreneurship Program, helping entrepreneurs scale up. Arta has 14 years of experience in private sector development with a substantial practice in developing economic policy at the national level. She was a Political Advisor to the Minister of Trade and Industry, focusing on the business climate. She worked for eight years in senior positions with international donor projects focusing on business development and marketing. Arta holds an MSc. in Economic Development \& Policy Analysis from the University of Nottingham, U.K. She is a Certified Digital Transformation Expert. The author can be contacted at arta.istrefi@gmail.com 